УДК $94: 351.74(477.73)$ «1941/1944» (043.2)

DOI: 10.26693/ahpsxxi2020.02.007

\title{
ДІЯЛЬНІСТЬ МІСЦЕВОЇ ПОЛІЦІї НА ПІВДНІ УКРАЇНИ У ПЕРІОД НІМЕЦЬКО-РУМУНСЬКОЇ ОКУПАЦІї (1941-1944 рр.)
}

\author{
Лідія Біліченко, \\ e-mail: bilichenko.lidia@gmail.com \\ ORCID: https://orcid.org/oooo-ooo1-5547-9248 \\ Чорноморсъкий національний університет імені Петра Могили, \\ Украӥна, 540о3, м. Миколаїв, вул. 68 Десантників, 10
}

У статті досліджується діяльність місцевої поліиій на території півдня України під час німецько-румунсъкої окупаціӥ регіону в 1941-1944 рр. Доведено, що українсъка допоміжна поліція сформувалася й активно використовувалася німецькою та румунською окупаційними режимами вже у перші місяці війни для підтримки «нового порядку» на захопленій територї. Встановлено, що основними напрямками роботи поліції були: охорона громадського правопорядку, розслідування кримінальних злочинів, затримання політично неблагонадійних осіб, участь у каральних операціях тощо.

Ключові слова: місцева поліція, Південь Украӥни, колабораціонізм, Друга світова війна, «Трансністрія», Рейхскомісаріат «Украӥна»

Постановка проблеми. Міфи на тему прогітлерівського колабораціонізму в роки Другої світової війни давно перетворилися не тільки в привід для спекуляцій, але і в ефективну зброю інформаційно-психологічної війни Російської Федерації проти України. У зоні окупації опинилося багато тисяч українців, яким неминуче доводилося вступати у контакти з німецькими та румунськими властями і навіть співпрацювати з ними. У наш час залишається майже недослідженою тема діяльності місцевої поліції на території півдня України в роки Другої світової війни. До сьогодні є лише одна праця одеського дослідника С. Богана ${ }^{1}$ яка прямо стосується зазначеного питання, що надзвичайно актуалізує цей напрямок дослідження.

Серед українських науковців, які опосередковано торкалися даної тематики, слід виокремити Т. Гарбуза 2 , I. Дерейка 3 , Б. Зека4, T. Мартиненка 5 , I. Тарнавського 6 . I хоча вони в цілому висвітлювали діяльність поліції на території Києва, Луцька, Львова та Донецька, все ж таки в їх працях згадується і поліція, яка діяла на Півдні України. Цінну інформацію про організацію та структуру допоміжної поліції на окупованих територіях ми зустрічаємо у монографії російського науковця Д. Жукова «Русские эсэсовцы». Виходячи з вищесказаного, автори поставили собі за мету, як на основі

\footnotetext{
${ }^{1}$ Боган, С. (2012). Колабораціоністські органи правопорядку на Півдні України у 1941-1944 pp. Наукові праці [Чорноморсъкого державного університету імені Петра Могили]. Сер.: Істоpiя, 180 (168), 35-40.

2 Гарбуз, Т., Задирко, Х. (2014). Масове винищення єврейського населення Херсонської та Миколаївської областей у період окупації 1941-1945 років. Acta studiosa historica, 4, 137-145.

3 Дерейко, I. (2012). Місцеві формування німецької армї та поліцій у Райхскомісаріаті «Україна»(1941-1944 роки). Київ: Ін-т історії України НАН України.

4 Зек, Б. (2013). Особовий склад української допоміжної поліції Луцька у 1941-1944 pp. Icmopuчні студї Східноєвропейського національного університету імені Лесі Украӥнки, 9-10, 105111.

5 Мартиненко, Т. (2013). Українська Допоміжна Поліція в окрузі Львів-місто: штрихи до соціального портрета. Вісник Львівсъкого університету. Сер.: Історична, 48, 152-167.

6 Тарнавський, I. (2017). Місцева допоміжна поліція Донеччини в період нацистської окупації (1941-1943рр.). Київські історичні студї, 1, 110-119.
} 
історіографічного матеріалу, так із залученням архівних джерел і періодики того часу, дослідити діяльність місцевої (допоміжної) поліції на Півдні України в 19411944 pp.

Виклад основного матеріалу. До кінця жовтня 1941 р. Південь України був майже повністю окупований німецько-румунськими військами. Особливістю окупаційної політики південноукраїнських земель було те, що ії територія увійшла до двох, різних окупаційних зон - підпорядкованого румунам губернаторства «Трансністрія» (спочатку з центром у Тирасполі, згодом - в Одесі) і захопленого німцями Рейхскомісаріату «Україна»7. Із південноукраїнських земель до губернаторства «Трансністрія» відійшли сучасні Одеська та західна частина Миколаївської області. Очільником було призначено Георге Алексіяну. Натомість, гауляйтером Рейхскомісаріату «Україна» став сумнозвісний Еріх Кох. На території сучасних Херсонської та Кіровоградської областей і східної частини Миколаївської області, що входили до Рейхскомісаріату «Україна», німці створили Миколаївський генеральний округ з центром у Миколаєві. На чолі округу став обергрупенфюрер Е. Оперман 8.

6 листопада 1941 р. рейхсфюрер СС і шеф німецької поліції Г. Гіммлер видав наказ про створення місцевої допоміжної поліції в Рейхскомісаріаті «Україна», яка отримала назву шуцман-шафт, або «шума». 19 листопада 1941 р. статус допоміжної поліції в зоні цивільного управління був остаточно закріплений у спільному наказі шефа СС Г. Гіммлера та міністра у справах окупованих східних територій А. Розенберга «Про підпорядкованість поліцейських служб на окупованих територіях». Керівництво створенням і діяльністю «шума» покладалося на командувача німецької поліції порядку («орпо») рейхскомісаріату «Україна»9. Структура поліції виглядала так: «індивідуальна служба» (Schutzmannschaft-Einzeldienst) по охороні порядку в містах (охоронна поліція, Schutzpolizei) і сільській місцевості (жандармерія, Gendarmerie); батальйони допоміжної поліції (Schutzmannschaft-Bataillonen); пожежна охорона (Feuerschutzmannschaft); допоміжна охоронна служба (Hilfsschutzmannschaft), призначена для охорони таборів військовополонених та тюрем ${ }^{10}$.

Як правило, міське поліцейське управління підпорядковувалося міській управі та керувало діяльністю поліцейських ділянок, а також паспортних столів і пожежної команди. У великих містах, що мали районний поділ, міському поліцейському управлінню підпорядковувалися районні поліцейські управи ${ }^{11}$. Разом із районною поліцією в деяких населених пунктах півдня України створювалася повітова, яка обслуговувала навколишні населені пункти. Також існували сільські поліцейські дільниці, які різнились лише кількісним складом, а структурою були однакові. У поселеннях, селах і хуторах поліцію очолював старший поліцейський або начальник поліції, якщо село було велике ${ }^{12}$.

На Херсонщині допоміжна поліція, значиться під двома назвами: «Команда української Народної міліції міста Херсона», або «Українська служба безпеки». Ця правоохоронна структура на чолі з їі першим начальником на прізвище Конрад була створена міською Херсонською управою 15 вересня 1941 р. Херсон був поділений на чотири районних міліцейських управління. Районні органи правопорядку діяли під назвою «Районова Управа Української служби безпеки». Саме під такою назвою діяла українська міліція у Голопристанському районі під керівництвом їі шефа Петра Классена та слідчого О. Тютюнника. На Миколаївщині та в самому Миколаєві украї-

\footnotetext{
7 Михайлуца, М., Тригуб, О. (2014). Релігійна політика окупантів на Миколаївщині: особливості, суть та наслідки (серпень 1941 - березень 1944 рр.). Краєзнавство, 1, 113.

8 Пагіря, О. (n.d.). Місця німецького та румунського терору на території Миколаївської області, 1941-1944 pp. Retrieved from http://territoryterror.org.ua/uk/publications/details/?newsid=426 9 Зек, Б. (2013), 106.

10 Дерейко, І. (2012). Місцеві формування німецької армї та поліцї у Райхскомісаріаті «Україна»(1941-1944 роки). Київ: Ін-т історії України НАН України, 65.

${ }_{11}$ Жуков, Д., Ковтун, И. (2010). Русские эсэсовцы. Москва: Вече, 55.

12 Тарнавський, I. (2017), 113.
} 
нські органи правопорядку діяли під звичною назвою «українська поліція»13.

На території «Трансністрії» головний жандармський інспекторат і поліцейські органи підкорялися губернаторові та Міністерству внутрішніх вправ Румунії. Префектура поліції Одеси підпорядковувалась губернаторові та мала на території міста 10 поліцейських дільниць. Поліцейські органи складались з карного відділу та таємної поліції (сигуранци). Сигуранца слідкувала за настроями окупованого населення і солдат румунських гарнізонів, боролась 3 партизанами та підпільними диверсійними групами. Інспекторат в’язниць підпорядковувався безпосередньо МВС Румунії ${ }^{14}$.

Набір до поліції здійснювався 3 місцевого населення. Кожен 3 потенційних новобранців повинен був зазначити в анкеті такі відомості про себе: прізвище, ім'я, побатькові, національність, громадянство, професію, сімейний стан, дівоче прізвище дружини, військове звання, зріст, форму обличчя, колір волосся та колір очей ${ }^{15}$. Після заповнення анкети підписувалося заява, в якій зазначалося: «Оголошую замість присяги, що подані мною дані відповідають дійсності. Заявляю далі, що я арійського походження, а саме серед моїх предків не було євреїв, та також що я не був членом комуністичної партії»16.

Причини, що спонукали людей до вступу в місцеву поліцію, були різні: ненависть до радянської влади через масові репресії та голодомор, обіцянки німецького керівництва надати незалежність українцям, тощо. Ще однією обставиною, котра певною мірою стимулювала вступ до поліції з середини 1942 р., було те, що служба в іiї рядах охороняла від вивезення на роботу до Німеччини, яка загрожувала передусім молодим юнакам. Але головна причина - бажання вижити у складних умовах окупації, уникнути голодної смерті. Часто добровольцям обіцяли гуртожиток і харчування, як у німецьких військових ${ }^{17}$. Але звичайно це були лише обіцянки. В Державному архіві Миколаївській області зберігається прохання німецького наглядача Щербакова Миколи Яковича про підвищення заробітної плати. Зазначається, що дана особа знаходиться на німецькій службі в селі Травники й отримує 50 марок зарплатні, якої не вистачає аби прогодувати свою родинуㄹ․

Під час проходження служби в поліції часто траплялися різні казуси. Так, для прикладу, в 1942 р. на Миколаївщині троє охоронців з прізвищами Макура, Щербак і Загін поїхали в село випити горілки. Але, по поверненню додому пізно вночі, вартовий не впізнав їх та вистрелив у Щербака, який йшов попереду. Щербак був відправлений до госпіталю, де йому була зроблена операція. Однак, стан його був дуже важкий і на наступний день він помер 19.

У південній Україні органи та підрозділи міліції (поліції) виконували найрізноманітніші функції й обов'язки: охорона громадського правопорядку, патрулювання вулиць, постій і регулювання вуличного руху, охорона громадських закладів тощо. Згідно закону № 80 від 6 лютого 1941 р. виданого полковником Борческу, на території Одещини та Миколаївщини поліція повинна заарештовувати тих громадян, які:

- зберігають зброю, амуніцію, вибухові речовини без дозволу;

- $\quad$ крадуть амуніцію та зброю із казарм, складів, фабрик, які належать державі або приватним особам;

- особи, які не виконують накази губернаторства «Трансністрії», повітових префектів і міських голів ${ }^{20}$.

Мешканці півдня України негайно повинні були повідомляти поліцію про осіб,

\footnotetext{
13 Боган, С. (2012), 36.

14 Білоусова, Л., Гейтан, О. та ін. (укл.) (2009). Документи Державного архіву Одеської області з історї Другої світової війни та ї̈ наслідків: огляд фондів. Одеса: ДАОО, 2.

15 Державний архів Миколаӥвської області. Ф. Р-1434. Оп. 1. Спр. 1. Арк. 6.

16 Там само. Арк. 5.

17 Тарнавський, I. (2017), 112.

18 Державний архів Миколаївсъкої області. Ф. Р-1434. Оп. 1. Спр. 2. Арк. 2.

19 Там само. Арк. 3.

20 Державний архів Миколаӥвської області. Ф. Р-1651. Оп. 1. Спр. 3. Арк. 11.
} 
які зберігають вдома: свинець, олово, цинк, алюміній, мідь, бронзу, стару резину, зброю, кулі, військову амуніцію тощо. Особи, у яких знайшли зазначені речі, засуджувалися до страти ${ }^{21}$. Заборонялося використовувати бензин та керосин в інших цілях окрім як для весняних посівів ${ }^{22}$. Також поліція слідкувала за тим, аби з наступом сутінок, світло у кожному будинку було всюди вимкнуто. У випадку коли відсутні віконні ставні та через неможливість повного затемнення, слід було залишатися без світла, не запалюючи ліхтарів 3 . Здійснювався поліцією й контроль за комерсантами ресторанів та буфетів. Їм суворо заборонялося продавати спиртні напої військовим. Якщо власник закладу не виконував зазначеного наказу, то його позбавляли права торгівлі та закривали буфети або ресторани, якими він володів ${ }^{24}$. Задля охорони правопорядку та запобіганню диверсій, населенню міст і сіл півдня України радилося не приймати на ночівлю осіб з інших місцевостей. Якщо приїжджав погостювати родич, то потрібно було заздалегідь повідомити про це органи поліції та прийти до поліцейських для перевірки особистості 25.

Поліцейські нерідко виконували й традиційні міліцейські функції у кримінальних справах ${ }^{26}$. У 1943 р. до відділу кримінальної поліції м. Миколаєва звернулася громадянка Марія Лілісон із заявою про крадіжку. Зазначена особа розповіла, що в 1942 р. до неї у гості прийшла її подруга Прочаєва Софія Григорівна зі своєю знайомою Портненко Ольгою Іванівною. На Портненко вона помітила шапку своєї покійної доньки, яка була вкрадена з їі квартири. В ході обшуку квартири Портненко, кримінальна поліція виявила ще низку вкрадених речей, які раніше належали Лілісон: капелюх дитячий (червоний), дитяча білизна та пояс від дитячого пальта. Усі речі були повернуті власниці 27.

1 березня 1943 р. о 3 годині дня Дедулям Георгій, який проживав по вулиці Кузнечній у будинку № 25, при виході на вулицю був затриманий трьома озброєними грабіжниками, які, поваливши його на землю, кілька разів вистрілили з револьверів, цілячись йому в голову. Грабіжникам вдалося зняти з потерпілого пальто та золоте кільце, а також витягнути гаманець, в якому було 6о0 марок і документи. Енергійними діями районної поліції вдалося зловити зловмисників, які опинилися неповнолітніми: Широкий Михайло (16 років), Осташенко Георгій (17 років), Скакунов Леонід (17 років).

Інший випадок стався 23 березня 1943 р., коли, при спробі втечі, поліцією були розстріляні «великий бандит» Одеси - нальотчик Іван Ананьєв, що носив прізвисько «Мордатий», i «за компанію» - двірник Віктор Красовський, який переховував його у себе. Розстріл злочинців стався при наступних обставинах: злочинці розповіли органам поліції, що на одній з околиць міста ними закопані у затишному місці цінності 3 числа викрадених ними під час останніх нальотів. Злочинці обіцяли чинам поліції вказати місце закопаних цінностей. Однак, при виході з машини вони намагалися втекти і не звертали уваги на неодноразові попередження зупинитися. Це змусило поліцейських, які супроводжували злочинців, відкрити вогонь, у результаті чого злочинці були вбиті ${ }^{2}$.

Займалася поліція також незначними правопорушеннями. Так, жителів с. Володимирівка Очаківського повіту в 1943 р. було доставлено поліцією до військового претора, через те, що ті поїхали на Адамовський млин молоти пшеницю, що було заборонено префектурою Очаківського повіту від 19 жовтня 1942 р. Загалом заарештували: Горлова Максима, Горлова Данила, Горлова Олександра, Спиридонова

\footnotetext{
21 Там само. Арк. 20.

22 Там само. Арк. 14.

23 там само. Арк. 16.

24 Там само. Арк. 25.

25 там само. Арк. 18.

26 Мартиненко, Т. (2013), 163.

27 Державний архів Миколаївської області. Ф. Р-1433. Оп. 1. Спр. 1. Арк. 3.

28 Военно-полевой суд (1943, 26 марта). Молва. Одесса, 3.
} 
Григорія, Баланда Петра, Степанова Іллю, Подопригору Петра, Запорожченко Юлію, Балановську Ганну, Таран Марію та Білоусова Трохима 29.

На українську поліцію була покладена й робота санітарних служб. Так, 22 вересня 1941 р. Херсонська міська управа видала розпорядження населенню «все почистити і обробити хлором, аби запобігти кишково-шлунковим захворюванням». Контроль за виконанням постанови здійснювався українською народною міліцієюзо. На Миколаївщині по першому попередженню поліції все населення від 2 до 70-ти років мали зробити протихолерне щеплення. Особи, які не зробили цього, були покарані штрафом або ж тюремним ув'язненням до 6 місяців ${ }^{31}$. Згідно 3 наказом губернатора «Трансністрії» від 27 травня 1943 р., контроль за виконанням якого покладався на міську поліцію, санітарний відділ і шефів секторів, усі жителі до 10 липня 1943 р. повинні відремонтувати та побілити свої будинки. При кожному дворі мав бути збудований і побілений клозет не менше ніж 2 м глибиною, а також вигрібна яма, куди мало викидатися сміття 32.

Ще одним напрямком роботи поліції був контроль за громадськими роботами та виконання функцій різних контрольно-ревізійних служб. За наказом № 10 губернатора «Трансністрії» поліцаї примусово виганяли усіх мешканців сіл (чоловіків, жінок, дітей) у поле для збору бур'янів. Звільнялися від робіт тільки хворі, старі люди та діти віком до 6 років33. Мешканці, які не захотіли виходити на роботи, були покарані місцевою поліцією як фізично (10 ударів батогом), так і штрафом (10 марок)34. Беручи до уваги те, що була велика потреба у фуражі для тварин (сіна, вівса, соломи та ячменю) (згідно з тим же наказом), мешканцям на території Одещини та Миколаївини не дозволялося палити солому для зігріву. Поліція повинна було слідкувати, щоб солома використовувалася тільки для харчування тварин35.

Також, через нестачу обмундирування солдат на фронті, з 25 жовтня 1942 р. Очаківський повіт постановив, що кожна родина, включаючи й німецькі сім ї, повинна була виготовити для солдат декілька пар шкарпеток і пару рукавиць. Контроль за здійсненням даної постанови було покладено на поліцію. Тi, хто не виконував зобов'язання каралися в'язницею від 15 діб до 3-х місяців, або ж штрафом у розмірі 50100 РККС 36.

Часто поліція займалася розшуком та арештом євреїв і виконували охоронні функції при єврейських гетто. Накази, розпорядження, інструкції румунської адміністрації дають нам уявлення про створення механізму дискримінації та фізичного знищення єврейського населення. Так, 11 листопада 1941 р. очільник румунського уряду Іон Антонеску видав наказ № 23, за яким:

«...враховуючи необхідність організації проживання євреїв у певних місцях з метою забезпечення безпеки тилу; також враховуючи, що єврейське населення має власною працею і засобами забезпечити своє існування, наказуємо:

Ст. 1. Всі євреї, які прибули до Трансністрії з районів військових дій або жили раніше в Трансністрії і переселилися в інші місцевості у зв'язку з військовими діями, а також і ті євреї, які в подальшому будуть переселені, - зобов'язані підкорятися правилам, викладеним у цьому наказі.

Ст. 2. Інспекторат Жандармерії Трансністрії встановлює місцевості, де євреї можуть поселятися; розселення проводиться, відповідно до числа членів сім’ї, в оселях, що залишилися. Кожна єврейська сім'я, яка отримала житло, повинна привести його в належний стан і утримувати його в чистоті. Якщо число таких жител виявиться не-

\footnotetext{
29 Державний архів Миколаївської області. Ф. Р-1651. Оп. 1. Спр. 3. Арк. 19.

$3^{30}$ Боган, С. (2012), 36.

31 Державний архів Миколаӥвської області. Ф. Р-1651. Оп. 1. Спр. 3. Арк. 22.

32 Там само. Арк. 24.

33 Там само. Арк. 9.

34 Там само. Арк. 15.

35 Там само. Арк. 7.

${ }^{36}$ Там само. Арк. 17.
} 
достатнім, євреї можуть бути поселені і на приватних квартирах, особливо їм для того зазначених, з встановленням певної квартирної плати.

Ст. 3. Всі євреї, що входять до складу кожного такого поселення або громади, повинні бути занесені в особливий список, де вказується: прізвище, ім'я, національність, релігія, вік, професія, місцевість, звідки прибув. Кожному єврею буде виданий відповідний документ з перерахуванням усіх вищенаведених даних.

Ст. 4. Жоден єврей не може залишити поселення, в якому йому призначено місце проживання, без особливого на те дозволу, виданого районним або повітовим префектом (начальником поліції).

Ст. 5. Всі євреї, що входять до складу одного поселення, утворюють колонію, яка управляється начальником колонії, який призначається претором району з середовища поселенців. Помічниками начальника колонії є керівники груп: начальник колонії призначає для кожної групи (в 20 чоловік) керівника, який несе відповідальність за наявність у групі всіх її членів, піклується про благополуччя їх і повідомляє про кожне порушення, допущене будь-ким з групи. Начальник колонії і керівники груп відповідають особисто за присутність всіх євреїв у колонії і за їх виконання адміністрації та жандармерії.

Ст. 6. Начальник колонії зобов'язаний подати списки всіх членів колонії, які володіють будь-якою спеціальною професією, всіх ремісників і взагалі всіх осіб, здатних до праці. На підставі списків, поданих начальником колонії. Міський Голова, або сільський староста, організовує працю в колонії і в місті або селі наступним чином: євреї, які володіють будь-якою спеціальною професією будуть знаходитися в розпорядженні управління колонії і будуть залучатися до роботи по мірі необхідності; майстри-ремісники будуть виконувати роботу, яка призначається їм відповідно до їх спеціальності; всі інші (особи некваліфікованої праці) будуть знаходитися у розпорядженні міських або сільських властей і будуть використовуватися на різних роботах для потреб колонії, або міста або села, або на інших роботах для суспільних потреб. Зокрема, вони будуть використані на польових роботах, на роботах з благоустрою доріг і мостів, по заготівлі лісу і дров, каменю та інших матеріалів. За пророблений робочий день видається продовольча картка в 2 марки, а для осіб некваліфікованої праці - в 1 марку. Органи жандармерії зобов'язані постійно перевіряти і контролювати стан єврейських колоній, доводячи до відома керівних органів про всі виявлені порушення.

Ст. 7. Залучення євреїв на роботу з однієї колонії в іншу проводиться з дозволу районного або повітового префекта. Залучення для робіт фахівців з одного району чи повіту в інший проводиться тільки з дозволу Директора відділу праці при Цивільному губернаторові.

Ст. 8. Кожен єврей, виявлений за межами своєї колонії без належного на те дозволу, буде розглядатися як шпигун і негайно покараний на підставі військових законів, що діють у воєнний час.

Ст. 9. Євреї-фахівці можуть бути з дозволу Губернатора використані на всіх роботах по відновленню промисловості, яка постраждала в результаті війни...»37.

Виконання даного розпорядження було покладено на місцеву поліцію.

На території Миколаївщини існували гетто у північних районах - у с. Криве Озеро, с. Мостове, м. Голта (Первомайськ). Особливу увагу треба звернути на так звані табори в с. Богданівка та с. Доманівка, які стали справжніми таборами смерті. Знищенням євреїв у Богданівці займалась оперативна група «Д», до складу якої входило 500 есесівців, керував ними Отто Олендорф. Охороняли табір 12 поліцаїв - жителі Богданівки на чолі з Іваном Сливенко, який відрізнявся особливою жорстокістю у ставленні до в’язнів. В'язням не давали ні їжі, ні води, доходило до того, що люди використовували взимку сніг для питної води. До грудня 1941 р. кількість померлих

37 Главное военное командование управление гражданского губернатора Транснистрии. Приказ № 23 (1941, 24 декабря). Одесская газета. Одесса, 5. 
дійшла до 2 тис. осіб. Загалом, на території с. Богданівки та с. Доманівки за увесь час існування гетто, було знищено 7540 людей 38 .

Бували випадки, коли німецька адміністрація залучала і до прямих розстрільних операцій. Зокрема, дані завдання покладалися на так звані шуцбатальйони. Так, 16 вересня 1941 р. німецькі жандарми та місцеві поліцаї зігнали всіх євреїв с. Бобровий Кут (єврейська колонія) на Херсонщині у двір маслозаводу, а потім погнали до глибокого закинутого колодязя в степу біля с. Євгенівка. Людей розстріляли, а їх трупи скинули у колодязь. За даними різних джерел кількість жертв становить до 850 осібз.

Під расову дискримінацію потрапляли не тільки люди єврейського походження. На півдні України строго заборонялося циганам продавати будь-які предмети одягу або ж домашнього вжитку. Також жителям міст не дозволялося купувати будь-які речі у циган. Цигани, що продавали мешканцям і мешканці, які купували у циган, були доставлені поліцією до військового претора та покарані тюремним ув’язненням строком від 2 до 6 місяців. Звичайно, у порівнянні з репресіями проти єврейського населення, це були дрібниці40.

Результати дослідження. Таким чином, українська допоміжна поліція сформувалася й активно використовувалася німецькою та румунською окупаційними режимами вже у перші місяці війни для підтримки «нового порядку» на захопленій території. Обов'язки поліції були різноманітні: охорона правопорядку, розкриття кримінальних злочинів, робота санітарних служб, відправка населення на господарські роботи, затримання політично-неблагонадійних осіб, охорона німецьких концтаборів, участь у каральних операціях тощо.

\section{REFERENCES}

Bohan, S. (2012). Kolaboratsionistski orhany pravoporiadku na Pivdni Ukrainy u 1941-1944 rr. [Collaboration law enforcement agencies in the South of Ukraine in 1941-1944]. Naukovi pratsi [Chornomorskoho derzhavnoho universytetu imeni Petra Mohyly]. Ser.: Istoriia, 180, (168), 3540 [in Ukrainian].

Dereiko, I. (2010). Mistsevi formuvannia nimetskoi armii ta politsii u Raikhskomisariati «Ukraina»(1941-1944 roky) [Local formations of the German army and police in the Reich Commissariat «Ukraine» (1941-1944)]. Kyiv: In-t istorii Ukrainy NAN Ukrainy [in Ukrainian].

Harbuz, T. (2014). Masove vynyshchennia yevreiskoho naselennia Khersonskoi ta Mykolaivskoi oblastei u period okupatsii 1941-1945 rokiv [Mass extermination of the Jewish population of Kherson and Mykolayiv regions during the occupation of 1941-1945]. Acta studiosa historica, 4, 137-145 [in Ukrainian]

Koval, H. (2014). Holokost $v$ yeureiskykh kolonïakh kolyshnoi Khersonskoi hubernii [The Holocaust in the Jewish colonies of the former Kherson province]. Retriered from http://historymoippo.blogspot.com/2014/o2/blog-post_23.html [in Ukrainian]

Martynenko, T. (2013). Ukrainska Dopomizhna Politsiia v okruzi Lviv-misto: shtrykhy do sotsialnoho portreta [Ukrainian Auxiliary Police in Lviv-city district: touches to the social portrait]. Visnyk Lvivskoho universytetu. Ser.: Istorychna, 48, 152-167 [in Ukrainian].

Mykhailutsa, M., Tryhub, O. (2014) Relihiina polityka okupantiv na Mykolaivshchyni: osoblyvosti, sut ta naslidky (serpen 1941 - berezen 1944 rr.) [Religious policy of the occupiers in Mykolayiv region: features, essence and consequences (August 1941 - March 1944)]. Kraieznavstvo, 1, 113-123 [in Ukrainian].

Pahiria, O. (N.d.). Mistsia nimetskoho ta rumunskoho teroru na terytorii Mykolaivskoi oblasti, 1941$1944 \mathrm{rr}$. [Places of German and Romanian terror in the territory of Mykolayiv region, 1941-1944]. Retriered from http://territoryterror.org.ua/uk/publications/details/?newsid=426 [in Ukrainian].

Tarnavskyi, I. (2017). Mistseva dopomizhna politsiia Donechchyny v period natsystskoi okupatsii (1941-1943 rr.) [Local auxiliary police of Donetsk region during the Nazi occupation (1941-1943)]. Kyiuski istorychni studii, 1, 110-119 [in Ukrainian].

${ }^{38}$ Гарбуз, Т., Задирко, Х. (2014), 140.

39 Коваль, Г. (2014). Голокост в єврейських колоніях колишнъої Херсонської губернї̈. Retrieved from http://historymoippo.blogspot.com/2014/o2/blog-post_23.html

4о Державний архів Миколаӥвськой області. Ф. Р-1651. Оп. 1. Спр. 3. Арк. 21. 
Zek, B. (2013). Osobovyi sklad ukrainskoi dopomizhnoi politsii Lutska u 1941-1944 rr. [Personnel of the Ukrainian auxiliary police of Lutsk in 1941-1944]. Istorychni studii Skhidnoievropeiskoho natsionalnoho universytetu imeni Lesi Ukrainky, 9-10, 105-111 [in Ukrainian].

Zhukov, D., Kovtun, I. (2010). Russkie esesovcy [Russian SS men]. Moskva: Veche [in Russian].

Lidiia Bilichenko,

Petro Mohyla Black Sea National University, Mykolaiv, Ukraine ORCID: https://orcid.org/oOOO-OOO1-5547-9248

\section{The local police activities in the South of Ukraine in German-Romanian occu- pation period (1941-1944)}

The article examines the activities of local police in southern Ukraine during the German-Romanian occupation of the region in 1941-1944. By the end of October 1941, the south of Ukraine was almost completely occupied by German-Romanian troops. On November 6, 1941, the Reichsfuihrer of the SS and the head of the German police, G. Himmler, issued an order to establish a local auxiliary police at the Reich Commissariat «Ukraine», which was called a shutsman-shaft, or "noise». As a rule, the city police department was subordinated to the city council and managed the activities of police stations, as well as passport desks and the fire brigade. In large cities that had a district division, the district police departments were subordinated to the city police department.

In Transnistria, the Chief Gendarmerie Inspectorate and the police were subordinated to the Governor and the Romanian Ministry of the Interior. The Odessa police prefecture was subordinated to the governor and had 10 police stations in the city. The police authorities consisted of the penal department and the secret police. Sigurantsa monitored the mood of the occupied population and the soldiers of the Romanian garrisons, fought against guerrillas and underground sabotage groups. The prison inspectorate reports directly to the Romanian Interior Ministry.

It was established that the main areas of police work were: protection of public order, investigation of criminal offenses, detention of politically unreliable persons, participation in punitive operations, etc.

Keywords: local police, South of Ukraine, collaborationism, Second World War, «Transnistria», Reichskommissariat «Ukraine» 